\title{
Indeks Berseri, Trend Penerimaan Pajak Daerah, Retribusi Daerah, Pendapatan Asli Daerah dan Kepatuhan Wajib Pajak Daerah di Magelang
}

\author{
Endang Kartini Panggiarti ${ }^{1}$, Eva Wulandari ${ }^{2}$, Agustina Prativi Nugraheni ${ }^{3}$ \\ ${ }^{1}$ Universitas Tidar, Magelang, Jawa Tengah, Indonesia
}

\section{INFO ARTIKEL \\ JEL Classification :}

H71, H25

\section{Keywords :}

local tax, original local revenue, consciousness, compliance local tax

\begin{abstract}
The destination of the research is to find out about development and trend of local taxes and retributions that can give influence toward Original Local Government Revenue in Magelang City. Local taxes and retributions are primary source besides another source of Original Local Government Revenue. The researcher want to know about increase and decrease trend of Original Local Government Revenue, Local Taxes and Retributions. This research can be test with two way. First, the researcher to do quantitative method with glow indexes analysis and regression test. The conclusions of a glow indexes analysis is original local government revenue, local taxes, and retributions are increasing. Beside of that the retributions are not as increase as original local government revenue and local taxes. That is make a different with local taxes that significantly increase with original local government revenue. That is give prove that the original local government revenue can be financed by local taxes that accepted in Magelang City Government. Second, test it to find out impact toward awareness or compliance of local taxpayer. The result shown that taxpayer awareness or compliance have increase are significantly. This proves that the most of society in Magelang City already have consciousness and compliance of local taxpayer and exactly know the contributions of local taxes to development in Magelang City nevertheless are not give directly impact toward local taxpayer.
\end{abstract}

\begin{abstract}
ABSTRAK
Tujuan dari penelitian ini adalah untuk mengetahui perkembangan dan tren pajak dan retribusi daerah yang dapat memberikan pengaruh terhadap Pendapatan Asli Daerah Pemerintah Kota Magelang. Pajak dan retribusi daerah adalah sumber utama selain sumber lain dari Pendapatan Asli Pemerintah Daerah. Peneliti ingin mengetahui tentang tren peningkatan dan penurunan Pendapatan Asli Daerah, Pajak, dan Retribusi Daerah. Penelitian ini dapat diuji dengan dua arah. Pertama, peneliti melakukan metode kuantitatif dengan analisis indeks Glow dan uji regresi. Kesimpulan dari analisis indeks Glow adalah pendapatan asli pemerintah daerah, pajak daerah, dan retribusi meningkat. Selain itu retribusi tidak sebesar pendapatan asli pemerintah daerah dan pajak daerah. Itu membuat perbedaan dengan pajak daerah yang meningkat secara signifikan dengan pendapatan asli pemerintah daerah. Itu membuktikan bahwa pendapatan asli pemerintah daerah dapat dibiayai oleh pajak daerah yang diterima di Pemerintah Kota
\end{abstract}


Magelang. Kedua, uji untuk mengetahui dampaknya terhadap kesadaran atau kepatuhan wajib pajak setempat. Hasil penelitian menunjukkan bahwa kesadaran atau kepatuhan wajib pajak mengalami peningkatan secara signifikan. Ini membuktikan bahwa sebagian besar masyarakat di Kota Magelang sudah memiliki kesadaran dan kepatuhan wajib pajak lokal dan tahu persis kontribusi pajak daerah terhadap pembangunan di Kota Magelang namun tidak memberikan dampak langsung terhadap wajib pajak local.

\section{Pendahuluan}

Salah satu sumber pembangunan suatu daerah adalah bersumber dari pajak. Pemerintah memiliki kewenangan untuk memungut pajak dari warga negaranya tanpa memberikan imbalan langsung dan warga Negara juga wajib memberikan pajaknya kepada pemerintah tanpa mengharapkan imbalan secara langsung. Pajak yang dibebankan kepada warga Negara pada prinsipnya ada dua jenis yaitu pajak Negara dan pajak daerah. Pajak daerah dan retribusi daerah merupakan sumber pendapatan asli daerah yang sangat bermanfaat untuk pembangunan daerah. Pada penelitian ini peneliti ingin mengetahui trend atau kecenderungan pajak daerah dan retribusi daerah dan pengaruhnya terhadap PAD di Kota Magelang sejak tahun 2008 - 2018. Penerimaan pajak dari kalangan UMKM di Magelang, Jawa Tengah (menurut Kompas.com) relative masih kecil. Kantor Pelayanan Pajak (KPP) Pratama Magelang mencatat tahun 2016, baru 5000 dari 15.000 UKM yang membayar pajak dengan nilai sebesar Rp16 miliar. Angka tersebut hanya sekitar 2\% dari total penerimaan pajak ang masuk KPP Pratama Magelang. Adapun realisasi penerimaan pajak tahun 2016 lalu sebesar Rp788 miliar. Langkah pemerintah untuk menyampaikan sosialisasi ke UMKM sudah sampai ke dinas-dinas terkait. Seperti yang dilakukan Direktorat Jenderal Pajak (DJP) Jawa Tengah 1 menggandeng Dinas Koperasi dan UKM Provisi Jawa Tengah untuk mensosialisasikan penurunan tariff $\mathrm{PPh}$ final bagi Wajib Pajak Usaha Mikro Kecil Menengah (UMKM) melalui Peraturan
Pemerintah (PP) Nomor 23 Tahun 2018. PP No 23 Tahun 2018 ini mengatur tentang Pajak Penghasilan dari usaha yang diterima atau diperoleh Wajib Pajak yang Memiliki Peredaran Bruto Tertentu. Melalui peraturan ini pemerintah menerapkan tariff $0,5 \%$ yang berlaku efektif mulai 1 Juli 2018 sebagia pengganti atas PP Nomor 46 tahun 2013 yang sebelumnya menerapkan tariff PPh Final 1 persen untuk UMKM. Langkah sosialisasi yang dilakukan adalah DJP Jateng 1 melakukan jemput bola dengan cara persuasive bekerjasama dengan Dinas Koperasi dan UKM Kabupaten dan Kota di Jawa Tengah agar bisa mengajak UMKM binaan di setiap daerah untuk mendaftar dan membayar pajak. Selain itu, DJP Jateng I juga menggandeng perguruan tinggi yang memiliki tax center untuk sama-sama menyampaikan program penurunan pajak $0,5 \%$ kepada UMKM di Jawa Tengah. DJP Jateng I mengatakan penurunan tariff pajak UMKM menjadi $0,5 \%$ ini bertujuan untuk meringankan pajak UMKM agar usaha mikro dapat tumbuh, loncat menjadi usaha kecil, menengah serta bisa menjadi usaha besar.

Data sampai 31 Desember 2017 di Jawa Tengah total ada 43 juta UMKM dan yang terdaftar di DJP Jawa Tengah 1 kurang lebih 100ribu UMKM dengan total setoran pajak Rp281 miliar. Potensinya pajak UMKM Rp2 triliun sehingga diharapkan di 2018 ini bisa menambah lagi total pembayaran $\mathrm{PPh}$ menjadi Rp300 miliar.

Selain itu juga ingin mengetahui apakah sejak disosialisasikan penurunan tariff pajak UMKM menjadi 0,5\%, kepatuhan wajib pajak di Kota Magelang semakin meningkat. Karena pertumbuhan UMKM khususnya di 
Kota Magelang sangat pesat dan tentunya diharapkan pajak UMKM yang terkumpul dari masyarakat pun semakin besar. Oleh karena itu, berdasarkan uraian diatas, peneliti sangat tertarik untuk mengetahui trend pajak daerah, retribusi daerah dan pendapatan asli daerah di Kota Magelang serta pengaruhnya terhadap kepatuhan wajib pajak.

\section{Telaah Teori dan Pengembangan Hipotesis}

\section{Pengertian Pendapatan Daerah}

Sonny (2011:2) menjelaskan tentang pendapatan daerah adalah semua hak daerah yang diakui sebagai penambahan nilai kekayaan bersih dalam periode anggaran tertentu (UU No. 32 Tahun 2004 tentang pemerintah daerah). Sonny juga menjelaskan bahwa pendapatan daerah berasal dari penerimaan dana perimbangan pusat dan daerah, juga yang berasal dari daerah itu sendiri yaitu pendapatan asli daerah serta lainlain pendapatan yang sah. Pada UndangUndang Nomor 32 tahun 2004 pasal 17 tentang pemerintah daerah dan UndangUndang Nomor 33 Tahun 2004 pasal 3 tentang perimbangan keuangan antara pemerintah pusat dan daerah menyebutkan sumber dari pendapatan daerah yaitu 1) Pendapatan Asli Daerah (meliputi pajak daerah, retribusi daerah, hasil perusahaan milik daerah dan hasil pengelolaan kekayaan daerah yang dipisahkan, dan lain-lain penerimaan yang sah); 2) dana perimbangan; 3) pinjaman daerah; dan 4) lain-lain penerimaan yang sah. Pajak daerah memiliki porsi pendapatan yang lebih besar dibandingkan dengan pendapatan lainnya. Oleh karena itu pajak daerah merupakan pendapatan yang paling potensial suatu daerah untuk penerimaan pendapatannya.

\section{Pengertian Pajak}

Soemitro dalam Resmi (2007: 1) menjelaskan pajak adalah iuran rakyat kepada kas Negara berdasarkan undang-undang (yang dapat dipaksakan) dengan tidak mendapatkan jasa timbal balik (kontraprestasi) yang langsung dapat digunakan untu membayar pengeluaran umum. Resmi (2005) mengatakan bahwa pajak dipungut oleh Negara baik pemerintah pusat maupun pemerintah daerah berdasarkan atau dengan kekuatan undang-undang serta aturan pelaksanaannya, dimana diperuntukkan bagi pengeluaran-pengeluaran pemerintah, yang bila dari pemasukannya masih terdapat surplus, dipergunakan untuk membiayai public investment.

Pajak merupakan penerimaan pemerintah yang digunakan untuk membiayai pembangunan yang berasal dari beberapa sumber yang dapat dibedakan antara penerimaan pajak dan bukan pajak. Penerimaan bukan pajak salah satunya adalah penerimaan pemerintah yang berasal dari pinjaman pemerintah, baik pinjaman dalam negeri maupun pinjaman luar negeri dan penerimaan dari badan usaha milik pemerintah sedangkan sumber penerimaan yang lainnya adalah berasal dari pajak (Suhendi, 2008). Penerimaan bukan pajak yang merupakan penerimaan pemerintah yang berasal dari pinjaman dapat digunakan untuk pembiayaan pembangunan yang mekanismenya diatur tersendiri.

Pajak juga dapat dipandang dari berbagai aspek, dari sudut pandang ekonomi pajak merupakan alat untuk menggerakkan ekonomi yang digunakan untuk meningkatkan kesejahteraan masyarakat. Pajak juga digunakan sebagai motor penggerak kehidupan ekonomi rakyat. Dari sudut pandang hukum pajak adalah masalah keuangan Negara, sehingga diperlukan peraturan-peraturan pemerintah untuk mengatur permasalahan keuangan Negara (Lucia, 2017).

\section{Pengertian Pajak Daerah}

Davey mengemukakan pendapatnya tentang pajak daerah yaitu: (a) pajak yang di pungut oleh pemerintah daerah berdasarkan pengaturan dari daerah sendiri, (b pajak yang dipungut berdasarkan peraturan pemerintah pusat tetapi penetapan tarifnya dilakukan oleh pemerintah daerah, (c) pajak yang ditetapkan dan atau dipungut oleh pemerintah daerah, (d) pajak yang dipungut dan diadministasikan oleh pemerintah pusat tetapi hasil pungutannya diberikan kepada pemerintah daerah. Berdasaarkan undang-undang No. 34 Tahun 2000 tentang perubahan atas UndangUndang No. 18 Tahun 1997 tentang pajak daerah maka ditetapkan pengaturan terhadap kewenangan pemungutan pajak dan retribusi sebagai berikut: (1) Pajak provinsi terdiri dari 
Pajak Kendaraan Bermotor (PKB) dan kendaraan diatas air, Bea Balik Nama Kendaraan Bermotor (BBNKB) dan kendaraan di atas air, Pajak Bahan Bakar Kendaraan Bermotor (PBBKB) dan pajak pengambilan dan pemanfaatan Air Bawah Tanah dan Air Permukaan (PPABT/AP); (2) Pajak Kabupaten/ Kota terdiri dari pajak hotel, pajak restoran,pajak hiburan, pajak reklame, pajak penerangan jalan, pajak pengambilan bahan galian golongan c dan pajak parkir; (3) Retribusi daerah terdiri dari retribusi jasa umum, retribusi jasa usaha dan retribusi perijinan tertentu.

\section{Pengertian Retribusi Daerah}

Retribusi Daerah adalah pungutan daerah sebagai pembayaran atas jasa atau pemberian izin tertentu yang khusus disediakan dan/atau diberikan oleh pemerintah daerah untuk kepentingan orang pribadi atau badan (Mardiasmo, 2018). Retribusi daerah adalah salah satu sumber pendapatan asli daerah yang dapat kita manfaatkan untuk pembangunan daerah di Kota Magelang. Retribusi daerah biasanya menjadi andalan pemerintah untuk pendapatan setelah pajak, walaupun tidak selalu stabil penerimaan setiap tahunnya karena banyak aspek-aspek yang berpengaruh diantaranya adalah andil masyarakat dan lingkungan di wilayahnya.

\section{Peranan Pajak Daerah dalam Mendukung Pembiayaan Daerah}

Pajak daerah merupakan salah satu bentuk peran serta atau kontribusi masyarakat dalam pembangunan suatu daerah. Pajak daerah ini adalah sumber pendapatan daerah yang paling penting untuk membiayai penyelenggaraan kepemerintahan dan pembangunan suatu daerah. Permasalahan yang umumnya dihadapi adalah upaya menggali potensipotensi strategis pendapatan daerah yang biasanya terbentur aspek lingkungan dan penciptaan sumber daya potensial yang menghasilkan keuntungan atau fasilitas yang dinikmati oleh masyarakatnya. Oleh karena itu, pemerintah yang ingin meningkatkan PAD (Pendapatan Asli Daerah) selalu melakukan inovasi dan kreativitas, menciptakan lahan atau wilayah yang dipunyainya untuk dikembangkan dan menjadi suatu obyek yang dapat dinikmati oleh masyarakat dalam daerah atau luar daerah.

Davey (1998) menjelaskan tentang kriteria pajak daerah secara spesifik terdiri dari empat hal yaitu pajak yang di pungut oleh pemerintah daerah berdasarkan pengaturan dari daerah sendiri; pajak yang dipungut berdasarkan peraturan pemerintah pusat tetapi penetapan tarifnya dilakukan oleh pemerintah daerah, pajak yang ditetapkan dan atau dipungut oleh pemerintah daerah, dan pajak yang dipungut dan diadministrasikan oleh pemerintah pusat tetapi hasil pungutannya diberikan kepada pemerintah daerah. Untuk mengaplikasikan teori ini pemerintah membuat peraturan daerah untuk melegalkan tentang pemungutan pajak daerah agar legal secara hukum. Seperti Perda Kota Magelang No. 16 Tahun 2011 tentang Pajak Derah yang mengatur adanya pajak hotel termasuk juga pajak rumah kost yang memiliki kamar lebih dari 10 kamar. Yang berisi antara lain pajak hotel adalah pajak pelayanan yang disediakan oleh hotel.

\section{Hipotesis}

Selain melakukan analisis diskriptif, peneliti juga mengajukan hipotesis berkenaan tingkat pajak daerah, tingkat retribusi daerah, tingkat PAD, tingkat kesadaran wajib pajak dan tingkat kepatuhan wajib pajak. Hipotesis yang diajukan adalah:

H1 : Tingkat pajak daerah berpengaruh positif terhadap tingkat PAD.

$\mathrm{H} 2$ : Tingkat retribusi daerah berpengaruh positif terhadap tingkat PAD.

H3 : Tingkat kesadaran wajib pajak berpengaruh positif terhadap tingkat PAD.

H4 : Tingkat kepatuhan wajib pajak berpengaruh positif terhadap tingkat PAD.

H5 : Tingkat pajak daerah, tingkat retribusi daerah dan tingkat kepatuhan wajib pajak daerah berpengaruh positif terhadap tingkat kesadaran wajib pajak daerah.

H6 : Tingkat pajak daerah, tingkat retribusi daerah dan tingkat kesadaran wajib pajak daerah berpengaruh positif terhadap tingkat kepatuhan wajib pajak daerah. 
Adapun kerangka berpikir penelitiannya ini adalah :

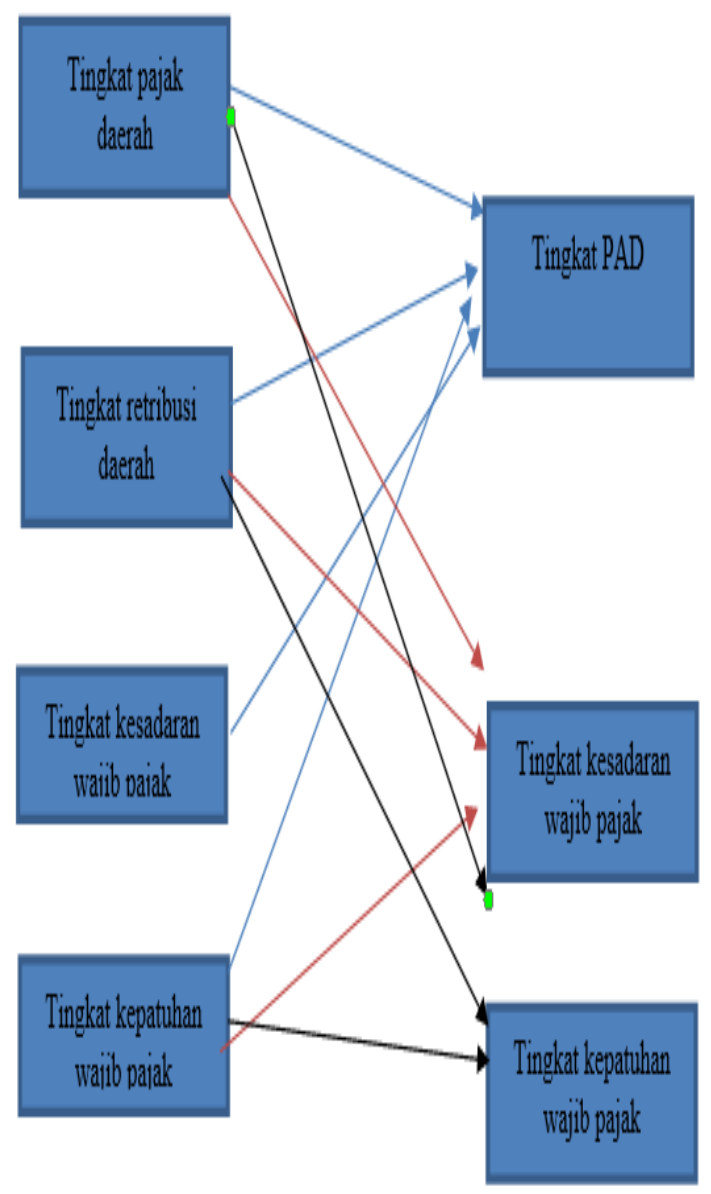

\section{Metode Penelitian}

Data yang digunakan dalam penelitian ini sebagian besar menggunakan data kuantitatif berupa Daftar Rincian Penerimaan Pendapatan Daerah Kota Magelang (20042018) dari Badan Pendapatan Keuangan Aset Daerah (BPKAD) Kota Magelang. Sumber data yang digunakan dalam penelitian ini yaitu data primer dan sekunder. Peneliti menggunakan kuesioner dari wajib pajak yang merupakan responden untuk mengetahui persepsi mereka tentang kesadaran dan kepatuhan wajib pajak. Data sekunder berupa target dan realisasi penerimaan Pendapatan Asli Daerah mulai tahun 2004-2018.

Teknik yang digunakan adalah studi lapangan di BPKAD Kota Magelang dan sekaligus merupakan objek penelitian ini untuk mendapatkan data tentang jumlah penerimaan $\mathrm{PAD}$, pajak daerah dan retribusi yang diperoleh selama tahun 2004 - 2018 di
Kota Magelang. Pada penelitian ini peneliti juga melakukan studi lapangan dengan menyebar sebanyak 50 kuesioner dengan kriteria responden bertempat tinggal di Kota Magelang dan memiliki usaha di Kota Magelang.

Penelitian ini adalah penelitian kuantitatif dan mengujinya dengan analisis statistik. Penelitian kualitatif menguraikan dan menggambarkan kondisi perekonomian dan pembangunan di Kota Magelang.

Penelitian ini menggunakan data primer dan mengambil sampel 50 orang untuk dijadikan responden. Kriteria responden adalah pengusaha atau orang yang memiliki usaha dan bertempat tinggal di Kota Magelang. Lima puluh orang untuk sampel telah memenuhi kriteria central limit theorem dengan minimal $\mathrm{n}=30$.

Penelitian ini menggunakan analisis statistik yaitu dari statistic diskriptif untuk mendapatkan nilai rata-rata, minimum dan maksimum dan standar deviasi, kemudian melakukan analisis faktor, uji reliabilitas dan valididitas, uji asumsi klasik dan analisis regresi. Maka model penelitian ini adalah:

$$
\begin{aligned}
& P A D= a+b_{1} P J K D a e+b_{2} \text { RetDae }+b_{3} \text { KepWP }+b_{2} \text { KesWP }+e \\
& \text { KepWP }=a+b_{1} \text { PJKDae }+b_{2} \text { RetDae }+ \text { KesWP }+e \\
& \text { KesWP }=a+b_{1} \text { PJKDae }+b_{2} \text { RetDae }+ \text { KepWP }+e
\end{aligned}
$$

Keterangan:

$$
\begin{array}{ll}
\text { PAD } & =\text { Tingkat Pendapatan Asli Daerah } \\
\text { PJKDae } & =\text { Tingkat Pajak Daerah } \\
\text { RetDae } & =\text { Tingkat Retribusi Daerah } \\
\text { KepWP } & =\text { Tingkat Kepatuhan Wajib Pajak } \\
\text { KesWP } & =\text { Tingkat Kesadaran Wajib Pajak } \\
\text { a } & =\text { konstanta } \\
\text { b } & =\text { koefisien } \\
\text { e } & =\text { residu }
\end{array}
$$

Untuk menghitung variable dependen dan independennya dilakukan dengan cara sebagai berikut:

\section{Tingkat PAD}

Untuk menghitung tingkat PAD adalah perbandingan antara jumlah PAD ke-n dan jumlah PAD selama 15 tahun dikalikan 100. 
Tingkat PAD $=\frac{\text { jumlah PAD tahun } k \theta^{-n} n}{j u m l a h \text { PAD selama } 15 \text { tahun }} \times 100$

\section{Tingkat Pajak Daerah}

Untuk menghitung tingkat pajak daerah adalah dari perhitungan perbandingan jumlah pajak daerah tahun ke-n dan jumlah pajak daerah selama 15 tahun dikalikan 100 .

Tingkat Pajak Daerah $=\frac{\text { jumlah Pajak Daerah tahun } k \theta^{-n}}{\text { jumlah Pajak Daerah selama } 15 \text { tahun }} \times 100$

\section{Tingkat Retribusi Daerah}

Untuk menghitung tingkat retribusi daerah adalah perbandingan jumlah retribusi daerah tahun ke-n dengan jumlah retribusi daerah selama 15 tahun yang kemudian dikalikan 100.

Tingkat Retribusi Daerah $=\frac{\text { jumlah Retribusi Daerah tahun ke-n }}{\text { jumlah Retirbusi Daerah selama } 15 \text { tahun }} \times 100$

\section{Tingkat Kesadaran Wajib Pajak}

Sebelum menentukan tingkat kesadaran wajib pajak, peneliti melakukan analisis faktor dan menentukan faktor mana yang dipilih. Kemudian memilih faktor yang memiliki loading faktor $>0,50$. Untuk tingkat kesadaran wajib pajak ada 6 faktor. Dari enam faktor tersebut peneliti membuat rata-rata untuk masing-masing $\mathrm{n}$ sampel.

\section{Tingkat Kepatuhan Wajib Pajak}

Sebelum menentukan tingkat kepatuhan wajib pajak, peneliti melakukan analisis faktor dan menentukan faktor mana yang dipilih. Kemudian memilih faktor yang memiliki loading faktor $>0,50$. Untuk tingkat kesadaran wajib pajak ada 6 faktor. Dari enam faktor tersebut peneliti membuat rata-rata untuk masing-masing $\mathrm{n}$ sampel.

Pada penelitian ini juga akan menguji dengan uji regresi. Pertama-tama yang peneliti lakukan adalah peneliti akan mengklasifikasikan jawaban dari responden sesuai dengan variable-variabel untuk menjawab hipotesis peneliti. Data tersebut kemudian diolah dengan program statistic spss versi 20. Data dari responden kemudian diolah dan dihitung dengan memasukkan nilai variabel baik independen dan dependen ke dalam persamaan regresi. Alat statistik yang digunakan untuk menguji hipotesis adalah uji regresi dengan multiple regression.

\section{Hasil Penelitian dan Pembahasan}

\section{Hasil yang Dicapai :}

Hasil penelitian ini terbagi menjadi beberapa bagian yaitu:

1. Uraian tentang proses pengambilan data. Responden diperoleh meliputi faktorfaktor demografis seperti nama, alamat rumah, nama usaha, dan alamat usaha.

2. Analisis diskriptif yang menunjukkan gambaran umum tingkat persepsi kesadaran dan kepatuhan wajib pajak serta data-data yang diperoleh dari BPKAD Kota magelang yaitu pajak daerah, retribusi daerah dan PAD. Pada bagian ini juga menampilkan analisis indeks berseri dan trend pendapatan asli daerah di Kota Magelang.

3. Analisis validitas dan reliabilitas instrument.

4. Analisis pengaruh pajak daerah, retribusi daerah, PAD, kesadaran wajib pajak terhadap kepatuhan wajib pajak.

\section{Proses Pengambilan Data}

Data penelitian yang digunakan dalam penelitian ini adalah data sekunder dan data primer. Data sekunder diperoleh dari Badan Pendapatan Keuangan dan Aset Daerah (BPKAD) Kota Magelang diperoleh data-data mengenai pajak daerah, retribusi daerah dan Pendapatan Asli Daerah (PAD) sejak tahun 2004 hingga tahun 2018 (15 tahun). Sedangkan data primer diperoleh dari responden. Calon responden yang digunakan sebagai sampel dalam penelitian ini berjumlah 50 responden dan peneliti gunakan 50 responden agar melebihi dari central limit theorem sebanyak $n=30$.

\section{Analisis Diskriptif dan Analisis Indeks Berseri}

Analisis diskriptif diperoleh dari data yang bersifat sekunder yaitu data tentang pajak daerah, retribusi daerah dan PAD selama tahun 2004 sampai dengan 2018 di Kota Magelang. Pada bagian ini peneliti juga akan melakukan analisis indeks berseri untuk melihat trend penerimaan PAD, pajak daerah dan retribusi daerah. Berikut ini adalah data tentang pajak daerah, retribusi daerah dan pendapatan asli daerah (PAD) dari tahun 2004 
sampai dengan tahun 2018 yang dapat dilihat pada tabel 1 .

Analisis diskriptif untuk PAD, pajak daerah, dan retribusi daerah Kota Magelang terdiri dari rata-rata, minimal, dan maksimal. Data penelitian ini selama 15 tahun menampilkan bahwa rata-rata PAD yang diperoleh yaitu Rp103.936.672.856, dengan minimal sebesar Rp22.628.250.565 dan maksimal sebesar Rp249.877.424.347. Pajak daerah rata-rata yang diperoleh sebesar Rp14.384.834.715, minimal sebesar Rp3.846.703.926 dan maksimal yang diperoleh sebesar Rp34.283.039.991. Sedangkan retribusi daerah rata-rata yang diperoleh sebesar Rp10.275.882.066, minimal sebesar Rp4.489.923.608 dan maksimal sebesar Rp21.525.877.597.

Untuk analisis indeks berseri yang meliputi trend penerimaan pajak daerah, retribusi daerah dan PAD di Kota Magelang terbagi menjadi 3 tahapan yaitu 5 (lima) tahun tahap 1, 5 (lima) tahun tahap ke dua dan 5 (lima) tahun tahap ketiga. Untuk tahap 5 tahun pertama, baik PAD, pajak daerah, dan retribusi daerah mengalami kenaikan, namun relative pada lima tahun terakhir untuk retribusi daerah. Pada tahap 5 tahun kedua, PAD dan pajak daerah mengalami kenaikan yang cukup signifikan tapi relative untuk retribusi daerah. Pada tahap 5 tahun ketiga, PAD dan pajak daerah meningkat relative dengan perubahan tahun dasar pada tahun 2014, namun retribusi daerah menurun sedikit demi sedikit. Berikut ini akan dijelaskan lebih terperinci pada masing-masing bagian.

Pada lima tahun tahap pertama dengan menggunakan angka indeks 100 pada tahun 2004 sebagai tahun dasar, PAD Kota Magelang meningkat dari 100 menjadi 163 di tahun 2006. Namun pada tahun 2007 sampai dengan tahun 2008 menurun relative yaitu menjadi 151 pada tahun 2009. Untuk pajak daerah dengan menggunakan tahun 2004 sebagai tahun dasar, angka indeks pajak daerah Kota Magelang meningkat signifikan dari 100 menjadi 130. Sedangkan untuk retribusi daerah dengan menggunakan tahun 2004 sebagai tahun dasar, angka indeks retribusi daerah meningkat dari 100 menjadi 128 pada tahun 2008, pernah meningkat sedikit yaitu menjadi 138 di tahun 2007 .
Pada lima tahun tahap ke dua, PAD, pajak daerah dan retribusi pajak daerah meningkat pesat. Dengan tahun 2010 sebagai tahun dasar, PAD Kota Magelang, meningkat dari 100 menjadi 462. Pajak daerah meningkat dari 100 menjadi 315 dan retribusi daerah meningkat dari 100 menjadi 164 .

Pada lima tahun tahap ke tiga, PAD, pajak daerah dan retribusi pajak daerah dengan menggunakan tahun 2014 sebagai tahun dasar. Data indeks berseri PAD meningkat dari tahun 2014 sebagai tahun dasar menjadi 152 pada tahun 2018, pajak daerah meningkat dari 100 pada tahun dasar 2014 meningkat menjadi 155, namun pada retribusi daerah dengan tahun dasar 100 pada tahun 2014 mengalami penurunan menjadi 93 pada tahun 2018, sempat naik pada tahun 2016 tapi menurun kembali pada tahun-tahun berikutnya. Hal ini terjadi karena ada beberapa pos di retribusi daerah yang tidak sesuai target yang telah ditetapkan BPKAD Kota Magelang. Untuk lebih jelasnya dapat dilihat pada tabel 1 .

\begin{tabular}{|c|c|c|c|c|c|c|}
\hline \multirow[t]{2}{*}{ TAHUN } & $\begin{array}{c}\text { PENDAPATAN } \\
\text { ASLIDAERAH } \\
(\mathrm{Rp}) \\
\end{array}$ & $\begin{array}{l}\text { ANGKA } \\
\text { INDEKS }\end{array}$ & $\begin{array}{c}\text { PAJAK } \\
\text { DAERAH } \\
(\mathrm{Rp}) \\
\end{array}$ & $\begin{array}{l}\text { ANGKA } \\
\text { INDEKS }\end{array}$ & $\begin{array}{c}\text { RETRIBUSI } \\
\text { DAERAH } \\
(\mathrm{Rp}) \\
\end{array}$ & $\begin{array}{l}\text { ANGKA } \\
\text { INDEKS }\end{array}$ \\
\hline & \multicolumn{6}{|l|}{ TAHAP 1} \\
\hline 2004 & $22,628,250,565$ & 100 & $3,846,703,926$ & 100 & $15,637,500,107$ & 100 \\
\hline 2005 & $28,640,254,757$ & 127 & $4,177,407,425$ & 109 & $17,058,036,288$ & 109 \\
\hline 2006 & $36,958,518,735$ & 163 & $4,411,071,647$ & 115 & $19,509,838,822$ & 125 \\
\hline 2007 & $5,814,844,996$ & 158 & $5,052,524,991$ & 31 & $1,525,877,597$ & 138 \\
\hline \multirow[t]{2}{*}{2008} & $4,149,190,382$ & 151 & $4,999,364,036$ & 30 & $20,082,573,395$ & 128 \\
\hline & \multicolumn{6}{|l|}{ TAHAP ? } \\
\hline 2009 & $23,342,759,951$ & 100 & $5,969,582,485$ & 100 & $4,489,923,608$ & 100 \\
\hline 2010 & $59,548,102,100$ & 255 & $6,717,893,095$ & 113 & $4,618,858,157$ & 103 \\
\hline 2011 & $63,557,701,976$ & 272 & $9,463,834,368$ & 159 & $5,281,990,063$ & 118 \\
\hline 2012 & $91,314,601,697$ & 391 & $12,546,890,184$ & 210 & $6,969,707,010$ & 155 \\
\hline \multirow[t]{2}{*}{2013} & $107,739,838,961$ & 462 & $18,829,673,340$ & 315 & $7,357,207,773$ & 164 \\
\hline & \multicolumn{6}{|l|}{ TAHAP 3} \\
\hline 2014 & $64,927,631,230$ & 100 & $22,107,435,949$ & 100 & $6,058,580,948$ & 100 \\
\hline 2015 & $186,677,410,081$ & 113 & $26,185,301,675$ & 118 & $6,999,474,592$ & 116 \\
\hline 2016 & $220,315,848,702$ & 134 & $5,974,837,133$ & 117 & $6,663,308,913$ & 110 \\
\hline 2017 & $233,557,714,356$ & 142 & $31,206,960,485$ & 141 & $6,243,021,736$ & 103 \\
\hline 2018 & $49,877,424,347$ & 152 & $34,283,039,991$ & 155 & $5,642,331,979$ & 93 \\
\hline
\end{tabular}

Untuk grafik analisis indeks berseri untuk 5 tahun tahap pertama dapat dilihat pada gambar 1 di bawah ini. Pada gambar grafik 1 dapat terlihat bahwa pajak daerah, retribusi daerah dan PAD dapat meningkat beriringan. Namun hal ini berbeda dengan 5 tahun tahap ke dua. Jarak peningkatan PAD menjauh dari pajak daerah dan retribusi daerah. Bahkan 
pada 5 tahun ke tiga, retribusi mengalami penurunan, hal ini berkebalikan dengan PAD dan pajak daerah yang beriringan mengalami peningkatan. Untuk lebih jelasnya dapat dilihat pada grafik $1-3$.

Peneliti juga ingin menggali informasi tentang tingkat kesadaran wajib pajak dan tingkat kepatuhan wajib pajak yang berasal dari responden yang dikumpulkan. Tabel 5 menunjukkan tingkat kesadaran wajib pajak responden yang terdiri 11 butir indicator. Secara umum, tingkat kesadaran wajib pajak responden cenderung moderat (rata-rata 3.31 dengan skala 1 - 5) dengan minimal 1 dan maksimal 5, artinya tidak terlalu rendah dan tidak terlalu tinggi.

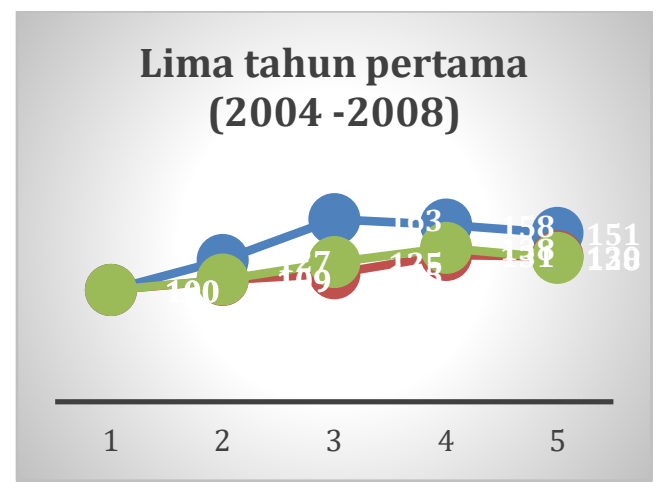

Gambar 1. Grafik 5 tahun tahap 1

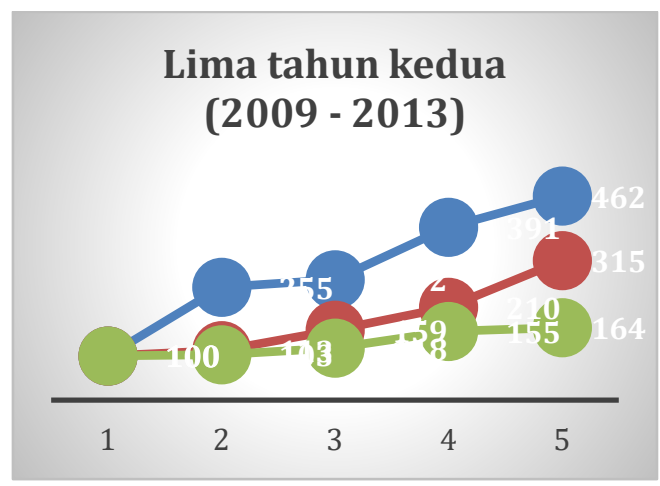

Gambar 2. Grafik 5 tahun tahap 2

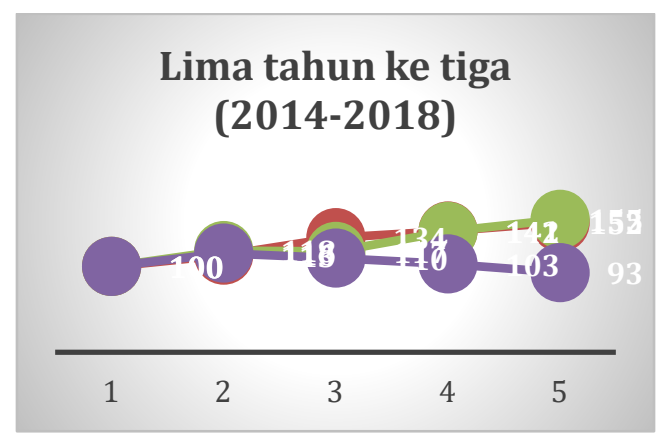

Gambar 3. Grafik 5 tahun tahap 3
Indicator-indikator yang memiliki skor rata-rata tertinggi berkaitan dengan memahami manfaat pembayaran pajak $(3,78)$ dan memahami kewajiban warga negara yang taat membayar pajak $(3,6)$. Sedangkan indicator yang memiliki skor rata-rata terendah berkaitan dengan budaya masyarakat kebanyakan tidak mempengaruhi pembayaran pajak $(2,4)$. Hal ini berarti faktor budaya dalam hal pembayaran pajak masih mempengaruhi perilaku wajib pajak tentang kesadarannya membayar pajak. Sedangkan faktor-faktor lainnya yang perlu mendapat perhatian adalah pendaftaran diri sebagai wajib pajak daerah, pemilikan NPWP Daerah, pemilikan NPWP daerah bagi pengusaha UMKM, jarak antara tempat tinggal dengan tempat pembayaran pajak ataupun pelaporan pajak, pembayaran pajak sebagai suatu kewajiban, dan pemahaman membayar pajak daerah.

\section{Analisis Uji Validitas dan Reliabilitas}

Uji validitas dan reliabilitas merupakan tahapan awal sebelum pengujian pengaruh antarvariabel. Uji validitas dilakukan untuk memastikan bahwa indicator yang digunakan benar-benar mengukur variable yang akan diukur. Uji reliabilitas dilakukan untuk memastikan konsistensi instrument di berbagai responden penelitian. Uji validitas penelitian ini menggunakan analisis faktor dan uji reliabilitasnya menggunakan koefisien Cronbach Alpha.

Kemudian peneliti melakukan analisis faktor konfirmatori untuk menguji apakah suatu konstruk mempunyai unidimensionalitas atau indicator-indikator yang digunakan dapat mengkonfirmasikan sebuah konstruk atau variable. Jika masingmasing indikator merupakan infikator pengukur konstruk variable maka akan memiliki nilai loading faktor yang tinggi (Ghozali, 2005).

Hasil uji validitas dan reliabilitas diatas untuk tingkat kesadaran wajib pajak valid dan reliable seperti yang dapat dilihat pada tabel 2 dan 3 di bawah ini. 
Tabel 2. Hasil uji validitas tingkat kesadaran pajak

\begin{tabular}{|c|c|c|c|c|c|}
\hline Variable & Konstruk & $\begin{array}{c}\text { Kaiser-Meyer- } \\
\text { Olkin Measure of } \\
\text { Sampling Adequacy. }\end{array}$ & $\begin{array}{r}\text { Approx. } \\
\text { Chil-Square }\end{array}$ & $\begin{array}{c}\text { Bartlett's } \\
\text { Test of } \\
\text { Sphericity }\end{array}$ & Simpulan \\
\hline V1 & 0,882 & 0,777 & 320.047 & 0,000 & Valid \\
V3 & 0,818 & & & & \\
V5 & 0,741 & & & & \\
V6 & 0,877 & & & & \\
\hline V7 & 0,865 & & & & \\
\hline V8 & 0,847 & & & & \\
\hline
\end{tabular}

Tabel 3. Hasil uji reliabilitas tingkat kesadaran wajib pajak

\begin{tabular}{|c|c|c|c|}
\hline Variable & $\begin{array}{c}\text { Cronbach's } \\
\text { Alpha if item } \\
\text { deleted }\end{array}$ & $\begin{array}{c}\text { Cronbachs } \\
\text { Alpha Based on } \\
\text { Standarized Items }\end{array}$ & Simpulan \\
\cline { 1 - 2 } V1 & 0,895 & \multirow{2}{*}{0,918} & Reliable \\
\cline { 1 - 2 } V3 & 0,903 & & \\
\cline { 1 - 2 } V5 & 0,915 & & \\
\cline { 1 - 2 } V6 & 0,901 & & \\
\hline V7 & 0,903 & & \\
\hline V8 & 0,901 & & \\
\hline
\end{tabular}

Hasil uji validitas dan reliabilitas untuk tingkat kepatuhan wajib pajak valid dan reliable seperti yang dapat dilihat pada tabel 4 dan 5 di bawah ini.

Tabel 4. Hasil uji validitas tingkat kepatuhan wajib pajak

\begin{tabular}{|c|c|c|c|c|c|}
\hline Variable & Konstruk & $\begin{array}{c}\text { Kaiser-Meyer- } \\
\text { Olkin Measure of } \\
\text { Sampling Adequacy. }\end{array}$ & $\begin{array}{r}\text { Approx. } \\
\text { Chi-Square }\end{array}$ & $\begin{array}{l}\text { Bartlett's } \\
\text { Test of } \\
\text { Sphericity }\end{array}$ & Simpulan \\
\hline $\mathrm{Wl}$ & 0,661 & \multirow[t]{11}{*}{0,820} & \multirow[t]{11}{*}{624.374} & \multirow[t]{11}{*}{0,000} & \multirow[t]{11}{*}{ Valid } \\
\hline W2 & 0,925 & & & & \\
\hline W3 & 0,788 & & & & \\
\hline W4 & 0,910 & & & & \\
\hline W5 & 0,686 & & & & \\
\hline W6 & 0,343 & & & & \\
\hline W7 & 0,418 & & & & \\
\hline W8 & 0,050 & & & & \\
\hline W9 & 0,912 & & & & \\
\hline W10 & 0,890 & & & & \\
\hline W11 & 0,498 & & & & \\
\hline
\end{tabular}

Tabel 5. Hasil uji reliabilitas tingkat kepatuhan wajib pajak

\begin{tabular}{|c|c|c|c|}
\hline Variable & $\begin{array}{c}\text { Cronbach's } \\
\text { Alpha if item } \\
\text { deleted }\end{array}$ & $\begin{array}{c}\text { Cronbachs } \\
\text { Alpha Based on } \\
\text { Standarized Items }\end{array}$ & Simpulan \\
\hline W1 & 0,941 & \multirow[t]{11}{*}{0,948} & \multirow[t]{11}{*}{ Reliable } \\
\hline W2 & 0,939 & & \\
\hline W3 & 0,941 & & \\
\hline W4 & 0,940 & & \\
\hline W5 & 0,941 & & \\
\hline W6 & 0,945 & & \\
\hline W7 & 0,945 & & \\
\hline W8 & 0,953 & & \\
\hline W9 & 0,942 & & \\
\hline W10 & 0,943 & & \\
\hline W11 & 0,948 & & \\
\hline
\end{tabular}

Sedangkan hasil validitas untuk variable tingkat kepatuhan pajak dapat dilihat dari beberapa tabel di bawah ini. Setelah melakukan analisis faktor yang hasilnya dapat dilihat pada tabel 25 di bawah ini, peneliti menemukan bahwa hanya 6 indikator dari 11 indikator yang memiliki loading faktor diatas 0,50 untuk tingkat kesadaran wajib pajak daerah dan hanya 7 indikator yang memiliki loading faktor diatas 0,50 untuk tingkat kepatuhan wajib pajak daerah. Hasil secara keseluruhan untuk tingkat kesadaran wajib pajak yaitu bahwa wajib pajak telah memiliki kesadaran untuk membayar pajak dan menyadari bahwa pembayaran pajak adalah suatu kewajiban yang harus dilakukan oleh seorang wajib pajak daerah. Hal ini juga didukung dengan tingkat kepatuhan wajib pajak daerah yang tinggi. Mereka telah memahami dan melakukan perhitungan serta pelaporan pajaknya sesuai ketentuan dan memahami betul dokumen serta sanksi yang akan diterima jika mereka lalai dalam pembayaran dan pelaporan pajaknya.

Tabel 6. Hasil Uji Validitas dengan Loading Faktor

\begin{tabular}{clll}
\hline No. & \multicolumn{1}{c}{ INDIKATOR } & Loading Factor \\
\hline 1 & Mendaftarkan diri sebagai Wajib Pajak Daerah & 0,882 \\
3 & $\begin{array}{l}\text { Memiliki NPWP Daerah adalah kewajiban } \\
\text { bagi pengusaha UMKM }\end{array}$ & 0,818 \\
& Memahami kewajiban sebagai warga daerah & 0,741 & \\
5 & yang taat membayar pajak & & \\
& Jarak antara tempat tinggal dengan tempat & & \\
6 & pembayaran pajak tidak mempengaruhi & 0,877 & \\
& motivasi membayar pajak & & \\
& Jarak antara tempat tinggal dengan tempat & & \\
7 & pelaporan pajak tidak mempengaruhi motivasi & 0,865 & \\
& melaporakan pajak & & 0,661 \\
8 & Pembayaran pajak adalah suatu kewajiban & 0,847 & 0,925 \\
\hline 12 & Kemampuan menghitung pajak dengan benar & & 0,788 \\
13 & Melaporkan pajak sesuai dengan ketentuan & & 0,910 \\
14 & Membayar pajak tepat waktu & 0,686 \\
15 & Melaporkan pajak tepat waktu & 0,912 \\
16 & Kesiapan dokumen & & 0,890 \\
\hline 20 & Menghitung pajak terutang dengan benar & \\
21 & Menyelesaikan tunggakan & \\
\hline
\end{tabular}

\section{Analisis Uji Pengaruh Antar Variabel}

Uji pengaruh antarvariabel dilakukan menggunakan analisis multiple regression. Peneliti ingin melakukan pengujian apakah pajak daerah dan retribusi daerah mempengaruhi peningkatan PAD di Kota Magelang. Setelah dilakukan pengujian SPSS versi 20 dengan regresi ternyata adjusted $R$ square-nya sangat tinggi yaitu 0,973 dan standar error of the estimates 0,13791274093 . Selain itu pengujian simultan ini sangat signifikan yaitu di bawah 0,00 . Walaupun peneliti kurang yakin karena jumlah tahun $\mathrm{n}=$ 15 , tapi bisa dipastikan bahwa pajak daerah 
memberikan proporsi utama terhadap PAD di Kota Magelang. Tabel 26 adalah hasil uji SPSS.

Tabel 7. Hasil uji SPSS

Model Summay ${ }^{b}$

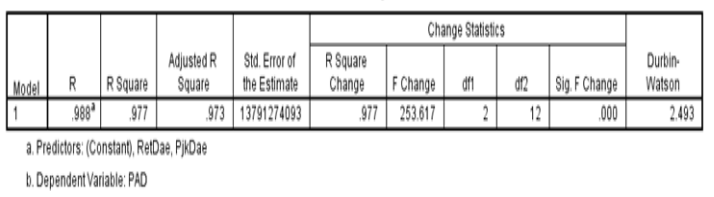

Untuk melihat hasil uji antar variable dengan $\mathrm{n}=15$, peneliti melakukan uji pengaruh dengan regresi SPSS versi 20 yang dapat dilihat pada tabel 27 di bawah ini. Berdasarkan tabel tersebut dapat dilihat bahwa variable pajak daerah memberikan pengaruh yang cukup signifkan terhadap PAD Kota Magelang sebesar 0,00 dengan koefisien 7,732. Sedangkan untuk retribusi daerah, memberikan hampir pengaruh signifikan sebesar 0,540 dengan koefisien 0,450.

Tabel 8. Hasil uji antar variable

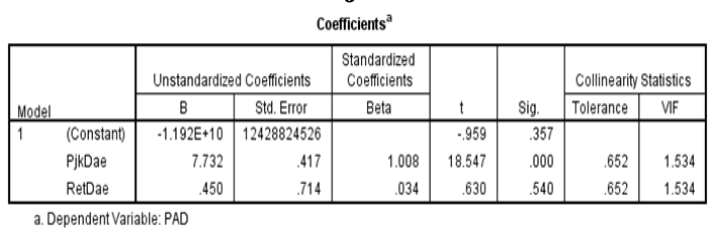

Kemudian terakhir, peneliti ingin menguji apakah tingkat kepatuhan wajib pajak mempengaruhi tingkat kesadaran wajib pajak di Kota Magelang. Hasilnya tingkat kepatuhan wajib pajak mempengaruhi tingkat kesadaran wajib pajak secara signifikan dengan adjusted $R$ square sebesar 0,547 . Hal ini dapat dilihat pada tabel 28 di bawah ini.

Tabel 9. Hasil uji pengaruh tingkat kepatuhan wajib pajak terhadap tingkat kesadaran wajib pajak

Mdele Summaris'

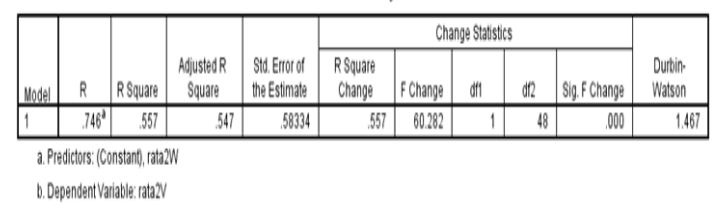

\section{Analisis Data dan Pembahasan}

Pada penelitian ini memang memiliki kelemahan yaitu jumlah sampel yang tidak sama. Peneliti tidak melakukan uji asumsik klasik, karena $\mathrm{n}=15$, di mana data merupakan jumlah PAD, jumlah Pajak Daerah dan Jumlah Retribusi Daerah selama 15 tahun.
Selain itu, juga memperoleh data dengan cara menyebar kuesioner untuk mengetahui persepsi responden tentang kesadaran dan kepatuhan pajak.

Berdasarkan hasil penelitian dan analisa data di atas, dapat diketahui bahwa pajak daerah mempengaruhi sebagian besar secara siginifikan PAD selama 15 tahun ini yang diperoleh dari BPKAD Kota Magelang. Sedangkan Retribusi Daerah memberikan pengaruh yang relative signifikan terhadap kontribusi PAD di Kota Magelang. Ternyata hal ini dikarenakan sebagian besar warga daerahnya telah memiliki kesadaran dan patuh taat membayar dan melaporkan pajak daerahnya. Terbukti tingkat kepatuhan wajib pajaknya sangat signifikan terhadap tingkat kepatuhan wajib pajaknya.

\section{Hasil Uji Hipotesis 1 sampai dengan hipotesis 4}

Langkah selanjutnya untuk menguji hipotesis, peneliti mencoba menguji pengaruh secara simultan dan parsial semua variable terhadap tingkat kesadaran wajib pajak dan tingkat kepatuhan wajib pajak dengan mengurangi jumlah responden menjadi 15 agar bisa diuji secara regresi. Hipotesis 1 sampai dengan 4 adalah menguji apakah tingkat pajak daerah (H1), tingkat retribusi daerah $(\mathrm{H} 2)$, tingkat kesadaran wajib pajak (H3) dan tingkat kepatuhan wajib pajak (H4) berpengaruh terhadap PAD di Kota Magelang. Hasil regresi linear di SPSS dapat dilihat pada tabel 10 di bawah ini.

Tabel 10. Hasil H1 - H4

Model Summary
\begin{tabular}{|l|r|r|r|r|r|}
\hline Model & \multicolumn{1}{|c|}{$R$} & R Square & $\begin{array}{c}\text { Adjusted R } \\
\text { Square }\end{array}$ & $\begin{array}{c}\text { Std. Error of } \\
\text { the Estimate }\end{array}$ & $\begin{array}{c}\text { Durbin- } \\
\text { Watson }\end{array}$ \\
\hline 1 & $.988^{\mathrm{a}}$ & .977 & .968 & .96803 & 2.465 \\
\hline
\end{tabular}
a. Predictors: (Constant), KpatuhnPjk, RetDae, PjkDae, KsadarnPjk
b. Dependent Variable: PAD

Berdasarkan tabel 29 dapat dilihat bahwa adjusted $R$ square-nya sangat tinggi, berarti model ini dapat dikatakan valid untuk menguji PAD, tingkat pajak daerah, tingkat retribusi daerah, tingkat kesadaran wajib pajak dan tingkat kepatuhan wajib pajak. Model ini juga sangat signifikan atau semua variable secara bersama-sama dapat mempengaruhi variable dependen secara simultan dan secara statistic signifikan. Seperti hasil yang dapat dilihat pada tabel 11 . 
Tabel 11. Hasil Uji Anova H1 - H4 ANOVA $^{\mathrm{a}}$

\begin{tabular}{|c|c|c|c|c|c|c|}
\hline Model & & $\begin{array}{l}\text { Sum of } \\
\text { Squares }\end{array}$ & df & Mean Square & $\mathrm{F}$ & Sig. \\
\hline \multirow[t]{3}{*}{1} & Regression & 396.832 & 4 & 99.208 & 105.870 & \\
\hline & Residual & 9.371 & 10 & .937 & & \\
\hline & Total & 406.203 & 14 & & & \\
\hline
\end{tabular}

Jika diuji secara parsial untuk masingmasing variable, hanya variable tingkat pajak daerah saja yang memberikan pengaruh secara signifikan menurut statistic dengan tingkat siginifikansi di bawah 0,05 , berarti hipotesis 1 diterima dengan koefisien 1,065. Tingkat retribusi daerah tidak memberikan tingkat signifikan karena di atas 0,578 atau hipotesis 2 diterima dengan koefisien 0,045 namun tidak signifikan secara statistik. Begitu juga dengan tingkat kesadaran wajib pajak (H3) yang hipotesisnya $\mathrm{H} 3$ nya diterima secara statistic namun tidak signifikan dengan koefisien 0,087 . Sedangkan tingkat kepatuhan wajib pajak (H4) tidak memberikan tingkat signifikan dan $\mathrm{H} 4$ tidak diterima karena koefisiennya $-0,107$. Hasil dari uji ini dapat dilihat pada tabel 12 di bawah ini.

\section{Tabel 12. Hasil Uji secara Parsial Antar Variabel pada H1-H4}

\begin{tabular}{|c|c|c|c|c|c|c|c|c|c|c|}
\hline \multirow[b]{2}{*}{ Model } & & \multicolumn{2}{|c|}{ Unstandardizad Cooficlients } & \multirow{2}{*}{ 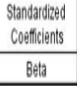 } & \multirow[b]{2}{*}{1} & \multirow[b]{2}{*}{ Sig. } & \multicolumn{2}{|c|}{ 95.0\% Confidence Interal for B } & \multicolumn{2}{|c|}{ Collinearity Statistics } \\
\hline & & $B$ & stat Eirof & & & & Lowes Bound & Upper Bound & Tolesantine & VF \\
\hline \multirow[t]{5}{*}{1} & (Constant) & .680 & 1.483 & & .458 & 859 & .3984 & 2.625 & & \\
\hline & Pijore & 1065 & .058 & 1.003 & 15.610 & .000 & .913 & 1.217 & 558 & 1.791 \\
\hline & RélDoje & 045 & 078 & 0.34 & 575 & 578 & . 128 & .218 & .844 & 1.554 \\
\hline & Ksodumpik & 087 & 678 & 012 & .126 & 900 & .1 .423 & 1.597 & 284 & 3.521 \\
\hline & Kpatuthpijk & .107 & .524 & .019 & 204 & 843 & -1.275 & 1.062 & .276 & 3.617 \\
\hline
\end{tabular}

\section{Hasil Uji Hipotesis 5}

Untuk hipotesis 5 adalah menguji apakah pajak daerah, retribusi daerah, dan tingkat kepatuhan wajib pajak berpengaruh terhadap tingkat kesadaran wajib pajak di Kota Magelang. Hasil regresi linear di SPSS dapat dilihat pada tabel 13 di bawah ini.

Tabel 13. Hasil hipotesis 5

Model Summary
\begin{tabular}{|l|c|r|r|r|r|}
\hline Model & $R$ & R Square & $\begin{array}{c}\text { Adjusted R } \\
\text { Square }\end{array}$ & $\begin{array}{c}\text { Std. Error of } \\
\text { the Estimate }\end{array}$ & $\begin{array}{c}\text { Durbin- } \\
\text { Watson }\end{array}$ \\
\hline 1 & $.846^{\text {a }}$ & .716 & .639 & .43071 & 2.300 \\
\hline
\end{tabular}
a. Predictors: (Constant), KpatuhnPjk, RetDae, PjkDae
b. Dependent Variable: KsadarnPjk

Berdasarkan tabel 32 dapat dilihat bahwa adjusted $R$ square nya relative tinggi yaitu sebesar 0,639, berarti model ini dapat dikatakan hanya sebesar $63,9 \%$ saja mampu mempengaruhi pajak daerah, retribusi daerah, PAD, dan tingkat kepatuhan wajib pajak, dan sisanya dipengaruhi oleh faktor-faktor lain. Model ini juga sangat signifikan atau semua variable secara bersama-sama dapat mempengaruhi variable dependen secara simultan dan secara statistic signifikan. Seperti hasil yang dapat dilihat pada tabel 14 di bawah ini.

Tabel 14. Hasil Uji Anova Hipotesis 5

ANOVA

\begin{tabular}{|c|c|c|c|c|c|c|}
\hline \multicolumn{2}{|c|}{ Model } & $\begin{array}{l}\text { Sum of } \\
\text { Squares }\end{array}$ & df & Mean Square & $\mathrm{F}$ & Sig. \\
\hline \multirow[t]{3}{*}{1} & Regression & 5.144 & 3 & 1.715 & 9.244 & $.002^{b}$ \\
\hline & Residual & 2.041 & 11 & . 186 & & \\
\hline & Total & 7.185 & 14 & & & \\
\hline
\end{tabular}

Jika diuji secara parsial untuk masingmasing variable, hanya variable tingkat kepatuhan wajib pajak memberikan pengaruh secara signifikan menurut statistic dengan tingkat siginifikansi di bawah $0,5 \%$ terhadap tingkat kesadaran pajak. Variable pajak daerah dan retribusi daerah tidak memberikan tingkat signifikan karena diatas 0,05 . Hasil dari uji ini dapat dilihat pada tabel 15 di bawah ini.

\section{Tabel 15. Hasil Uji secara Parsial Antar Variabel pada Hipotesis 5}

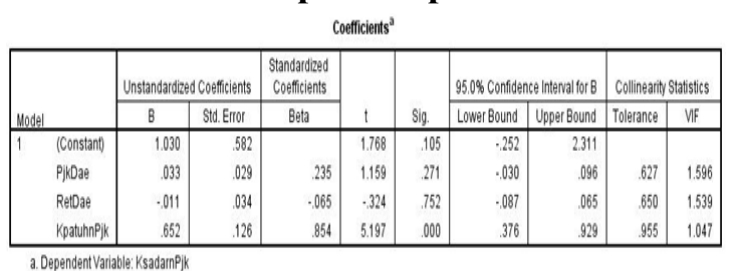

\section{Hasil Uji Hipotesis 6}

Untuk hipotesis 6 adalah menguji apakah pajak daerah, retribusi daerah, dan tingkat kesadaran wajib pajak berpengaruh terhadap tingkat kepatuhan wajib pajak di Kota Magelang. Hasil regresi linear di SPSS dapat dilihat pada tabel 16 di bawah ini.

Tabel 16. Hasil hipotesis 6

Model Summary
\begin{tabular}{|l|c|r|r|r|r|}
\hline Model & $R$ & R Square & $\begin{array}{c}\text { Adjusted R } \\
\text { Square }\end{array}$ & $\begin{array}{c}\text { Std. Error of } \\
\text { the Estimate }\end{array}$ & $\begin{array}{c}\text { Durbin- } \\
\text { Watson }\end{array}$ \\
\hline 1 & $.851^{\text {a }}$ & .724 & .648 & .55658 & 1.817 \\
\hline
\end{tabular}
a. Predictors: (Constant), KsadarnPjk, PjkDae, RetDae
b. Dependent Variable: KpatuhnPjk

Magister Akuntansi Universitas Pancasila 
Berdasarkan tabel 16 dapat dilihat bahwa adjusted $R$ square-nya relative sedang yaitu sebesar 0,615, berarti model ini dapat dikatakan hanya sebesar $64,8 \%$ saja mampu mempengaruhi pajak daerah, retribusi daerah, dan tingkat kesadaran wajib pajak, PAD, dan sisanya dipengaruhi oleh faktor-faktor lain.. Model ini juga sangat signifikan atau semua variable secara bersama-sama dapat mempengaruhi variable dependen secara simultan dan secara statistic signifikan karena di bawah 0,05 . Seperti hasil yang dapat dilihat pada tabel 17 di bawah ini.

Tabel 17. Hasil Uji Anova Hipotesis 6 ANOVA $^{\mathrm{a}}$

\begin{tabular}{|ll|r|r|r|r|r|}
\hline \multicolumn{2}{|l|}{} & \multicolumn{1}{|c|}{$\begin{array}{c}\text { Sum of } \\
\text { Sodel }\end{array}$} & \multicolumn{1}{c|}{ df } & Mean Square & F & Sig. \\
\hline 1 & Regression & 8.917 & 3 & 2.972 & 9.596 & $.002^{6}$ \\
& Residual & 3.408 & 11 & .310 & & \\
& Total & 12.325 & 14 & & & \\
\hline
\end{tabular}

a. Dependent Variable: KpatuhnPjk

b. Predictors: (Constant), KsadarnPjk, PjkDae, RetDae

Jika diuji secara parsial untuk masingmasing variable, hanya variable tingkat kesadaran wajib pajak memberikan pengaruh secara signifikan menurut statistic dengan tingkat siginifikansi di bawah 0,05 terhadap tingkat kepatuhan pajak. Variable pajak daerah dan retribusi daerah tidak memberikan tingkat signifikan karena diatas 0,05. Hasil dari uji ini dapat dilihat pada tabel 18 di bawah ini.

Tabel 18. Hasil Uji secara Parsial Antar Variabel pada Hipotesis 6

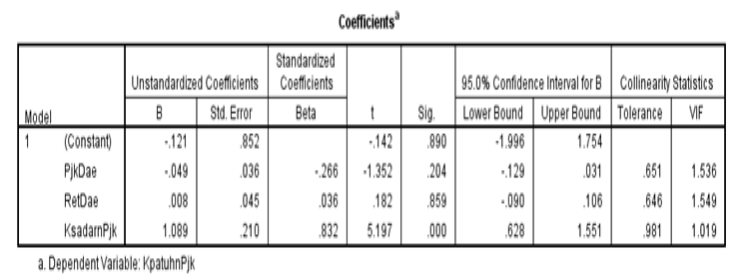

\section{Kesimpulan, Keterbatasan dan Implikasi Hasil Penelitian}

Kesimpulan hasil penelitian ini adalah:

1. Hipotesis 1 - 4 diterima yaitu variable pajak daerah, retribusi daerah, tingkat kepatuhan wajib pajak dan tingkat kesadaran wajib pajak secara simultan mempengaruhi PAD di Kota Magelang dan secara statistic signifikan. Namun hanya H1 saja yang diterima secara statistic signifikan, sedangkan hipotesis $\mathrm{H} 2$ dan $\mathrm{H} 3$ diterima namun tidak signifikan. Untuk H4 tidak diterima, berarti tingkat kepatuhan wajib pajak tidak berpengaruh terhadap PAD di Kota Magelang.

2. Hipotesis 5 yaitu menguji variable tingkat pajak daerah, tingkat retribusi daerah, dan tingkat kepatuhan wajib pajak secara simultan berpengaruh positif terhadapa tingkat kesadaran wajib pajak dan memberikan secara statistic signifikan. Hal ini berarti $\mathrm{H} 5$ diterima.

3. Hipotesis 6 yaitu menguji variable tingkat pajak daerah, tingkat retribusi daerah dan tingkat kesadaran wajib pajak secara simultan berpengaruh positif pada tingkat kepatuhan wajib pajak yang memberikan secara statistic signifikan. Hal ini berarti H6 diterima.

Implikasi hasil penelitian ini yaitu:

1. Hasil penelitian ini diharapkan dapat memberikan gambaran dan menjadi hasil evaluasi bagi BPKAD untuk menilai tentang pelayanan dan pendapatan pajak daerah selama ini.

2. Hasil penelitian ini bermanfaat bagi kebijakan pajak daerah di masa depan bagi pemerintah Kota Magelang.

3. Dapat sebagai wawasan dan pengetahuan tentang perkembangan pendapatan pajak daerah, retribusi dan PAD Kota Magelang yang bermanfaat untuk meningkatkan pelayanan bagi masyarakat dan meningkatkan pembangunan kota di masa depan.

Saran yang diharapkan peneliti untuk penelitian selanjutnya adalah:

1. Dapat menambah variable yang mempengaruhi variable tingkat kesadaran wajib pajak atau tingkat kepatuhan wajib pajak. Serta mampu menemukan model yang tepat yang dapat diimplementasikan agar masyarakat yang belum sadar pajak menjadi sadar pajak, yang belum patuh atau taat bayar atau lapor pajak menjadi patuh bayar lapor pajak.

2. Peran aktif pemerintah daerah daerah lebih proaktif dalam melayani masyarakat, sehingga hasil pajak daerah yang disetorkan oleh masyarakat ke daerah mampu dirasakan oleh masyarakat. 
3. Untuk ke depan diharapkan pemerintah daerah mampu menemukan peluang baru untuk meningkatkan PAD dari sumber lain, sehingga masyarakat menjadi lebih sejahtera karena pembiayaan pembangunan yang bermanfaat dan berkontribusi.

Keterbatasan penelitian ini diantaranya adalah:

1. Variable yang digunakan hanya 3 yaitu pajak daerah, retribusi daerah dan PAD, serta kepatuhan dan kesadaran pajak daerah, bisa ditambahkan variable lain seperti faktor demografi, edukasi dan lainlainnya.

2. Sampel yang diambil hanya 50 sampel dan responden hanya untuk wajib pajak yang patuh, mungkin ke depan bisa lebih diperluas dengan menambah sampel dan menambah klasifikasi pekerjaan atau daerah tertentu di Kota Magelang, untuk mengetahui tingkat kesadaran dan kepatuhan pajak di masing-masing daerah.

\section{Daftar Pustaka}

Devas, N. (1989). Keuangan pemerintah daerah di Indonesia. Penerbit Universitas Indonesia.

Ghozali, I. (2005). Aplikasi analisis multivariate dengan SPSS. Semarang: Badan Penerbit UNDIP.

Ghozali, I. (2009). Ekonometrika: teori, konsep dan aplikasi dengan SPSS 17. Semarang: Badan Penerbit Universitas Diponegoro.

Harahap Sofyan, S. (2001). Teori Akuntansi Edisi Revisi, PT. Raja Grafindo Persada Jakarta.

Horngren, C. T. H., Walter, T., \& Bamber, L. S. (2009). Akuntansi, Edisi ke-6, Jilid 1. PT Indeks, Jakarta.

Indonesia, R., \& Nomor, P. P. (2000). Undang-Undang No. 34 Tahun 2000 Tentang. Pajak dan Retribusi Daerah.

Indonesia, R. (2005). Undang-Undang No. 33 Tahun 2004 tentang Perimbangan Keuangan Pusat dan Daerah.
Indonesia, R., \& Nomor, U. U. (28). Tahun 2009 tentang pajak daerah dan retribusi daerah. Undang-Undang Nomor, 33.

Indrawati, L. R., Panggiarti, E. K., \& Laut, L. T. (2017). Perspektif Pajak Daerah Bagi Pendapatan Asli Daerah Kota Magelang. Jurnal REP (Riset Ekonomi Pembangunan), 2(1), 139-150.

Ilyas, W., \& Burton, R. (2011). Hukum Pajak dan Perpajakan. Edisi Kelima. Jakarta: Salemba Empat.

Jerry, J., Weygandt, D. E. K., \& Pauld, D. K. (2008). Pengantar Akuntansi Edisi 7. Jakarta: Salemba Empat.

Mahmudi. (2010). Analisis Laporan Keuangan Pemerintah Daerah. Yogyakarta: Sekolah Tinggi Ilmu Manajemen.

Mardiasmo. (2018), Tax, Revisi 2018, Yogyakarta : Penerbit Andi.

Memah, E. W. (2013). Efektivitas dan Kontribusi Penerimaan Pajak Hotel dan Restoran terhadap PAD Kota Manado. Jurnal EMBA: Jurnal Riset Ekonomi, Manajemen, Bisnis dan Akuntansi, 1(3).

Pemerintah Kabupaten Badung Dinas Pendapatan Daerah. (2012). Peraturan Daerah Kabupaten Badung. Badung.

Perda No. 11 Tahun 2016 Kota Magelang, tentang Pajak Daerah.

Resmi, S. (2007). Perpajakan Teori dan Kasus Jilid 2. Edisi Keenam. Salemba Empat, Jakarta.

Siahaan, M. P. (2010). Pajak daerah dan retribusi daerah edisi revisi. Jakarta: Rajawali Pers.

Stice, E. K., Stice, J. D., \& Skousen, F. (2009). Akuntansi Keuangan Menengah, Edisi 16, Buku 2. Edisi Bahasa Indonesia. Terjemahan Oleh Ali Akbar. Salemba Empat. Jakarta.

Sukrisno, A., \& Trisnawati, E. (2010). Akuntansi Perpajakan Edisi 2 
Endang Kartini Panggiarti, Eva Wulandari, Agustina Prativi Nugraheni : Indeks Berseri, Trend Penerimaan Pajak Daerah, Pendapatan Daerah dan Kepatuhan Pajak Daerah di Magelang

Revisi. Jakarta: Penerbit $\quad$ Salemba $\quad$ Wirawan, N. (2001). Statistik 1 (Statistik
Empat.

Undang-undang, Republik Indonesia Nomor 34 Tahun 2004 tentang. Pemerintahan Daerah. 